DOI https://doi.org/10.32782/2305-9389/2020.23.18

УДК [321.01+81'42+001.82](091)(477)

\author{
Яковлєв Максим, \\ кандидат політичних наук, доцент, \\ завідувач кафедри міжнародних відносин $і$ керівник \\ НОЦ «Школа політичної аналітики» \\ Національного університету «Києво-Могилянська академія»
}

\title{
ІСТОРІЯ ПОЛІТИЧНОЇ ДУМКИ КРІЗЬ ПРИЗМУ МІЖДИСЦИПЛІНАРНИХ ЛІНГВОПОЛІТОЛОГІЧНИХ ДОСЛІДЖЕНЬ
}

\begin{abstract}
У статті розглядаються можливості міждисциплінарних досліджень історії політичної думки, особливо в контексті України, крізь методологічну призму, в якій використовуються напрацювання політичної лінгвістики та дискурс-аналізу, зокрема в иарині лінгвополітології, лінгвістичної персонології політиків, політичної метафорології, порівняльних досліджень політичної комунікації, а також методів критичного дискурс-аналізу та суміжних дисциплін. Із досить широкого спектра лінгвополітологічних досліджень у статті розглядається уральська школа політичної лінгвістики, основні напрями якої стисло викладаються та коментуються в контексті подібних напрямів дослідження в інших краӥнах, на основі чого окреслюються майбутні перспективи застосування лінгвополітичних напрацювань у царині історії політичної думки України. Далі розглядаються основні напрями критичного дискурс-аналізу, з огляду на закладені в їхню основу методологічні та ідеологічні засади аналізу. Розглянутий матеріал дає змогу твердити, щзо для дослідження історії політичних ідей особливо актуальними видаються напрацювання політичної лінгвоперсонології, що займається ідіостилями конкретних ідеологів чи мислителів, для розуміння полемічних творів яких варто скористатися методиками політичної метафорології. Розуміння жанрової та стилістичної специфіки політичної комунікації, особливо креалізованих політичних текстів та жанрів, можна поєднати з методологічним апаратом постколоніальних студій, щзо $\epsilon$ особливо актуальним для дослідження історії украӥнської політичної думки та проявів постколоніалізму в ній. Видається перспективним дослідження семіотичних відображень соціального конфлікту в політичному дискурсі, ще дасть змогу розглядати ідеології як системи знаків і символів та застосувати до них методологї критичного дискурс-аналізу, зокрема соиіокогнітивний підхід Т. ван Дейка та дискурсивно-історичний підхід P. Водак, в межах якого поєднується текстуальний $і$ контекстуальний рівні аналізу політичного дискурсу $і$ який здійснює де- та реконтекстуалізаџію текстів та дискурсів, щзо кидає особливий виклик дослідженню історії політичних ідей через загрозу презентизму.
\end{abstract}

Ключові слова: політичні теорії, історія політичної думки, дискурс-аналіз, міждисциилінарні лінгвістичнополітологічні дослідження.

\section{Yakovliev Maksym. History of political thought through the lens of inerdisciplinary linguistic- political studies}

This article discusses the possibilities of interdisciplinary studies of political thought, in particular in Ukrainian context, through the methodological lens that combines political linguistics and discourse analysis in the realms of "linguopolitology", studies of linguistic styles of people - linguistic "personology" of politicians, studies of political metaphors, comparative studies of political communications, and also methods of critical discourse analysis. Since studies in political linguistics are very broad, one school is selected for analysis: the Ural school of political linguistics. Its main research areas are outlined, briefly presented and discussed, with examples of other similar studies into the complicated relations between language and politics. Based on that, the future, potential ways of applying linguistic research tools to analysis of how the political thinking in Ukraine evolved are briefly outlined. In addition, main strains of critical discourse analysis are also presented with a particular focus on their methodological foundations. All this together shows that the history of political ideas can be studied by means of analysing political languages of philosophers and ideologists, since this knowledge can contribute a lot to a better understanding of their polemics and arguments. A study in political metaphor seems very promising in understanding the genres and styles of political communication and in getting a holistic picture of political and social contexts in which certain political ideas evolved. The studies of creolisation processes can be enhanced by applying the methodology of postcolonial studies to them since it can greatly contribute to the studies of Ukrainian political thought and to postcolonial manifestations in it. Studies of semiotic reflections of social conflicts within political discourses enable a deeper analysis of political ideologies as systems of icons and symbols. They can be studied within the socio-cognitive approach of T. van Dijk or discursive-historical approach of $R$. Wodak that combines the textual and contextual levels of analysis. However it also implies de-and re-contextualisation of texts and discourses that, in turn, poses the risk of presentism in the studies of history of political thought.

Key words: political theory, history of political thought, discourse analysis, interdisciplinary political linguistic studies. 
Постановка проблеми в загальному вигляді. Дослідження історії політичної думки вимагає від науковців глибокого розуміння не лише фактажу подій, які супроводжували становлення тих чи інших поглядів та організацію тогочасного суспільно-політичного життя, але й опанування ними категоріально-понятійного апарату, за допомогою яких ці погляди висловлювалися, обговорювалися, обгрунтовувалися. Приміром, представники Кембриджської школи інтелектуальної історії особливо наголошують на тому, що мова, з одного боку, своїми засобами уможливлює висловлювання та обгрунтування певних позицій, з іншого боку, обмеженість мовленнєвих засобів також обмежує і можливості політичних а́кторів висловлюватися та аргументувати свої ідеологічні позиції [1]. Історія політичної думки навряд чи може бути висловлена інакше, ніж за допомогою різних мовних засобів, які в сукупності формують політичний та ідеологічний дискурси. Розуміння того, яким чином змінювалися мовні засоби політичної аргументації, способи говоріння про світ та процеси в ньому, може допомогти більш глибокому дослідженню форми та змісту політичних ідеологій в історичному розрізі їхнього розвою. На жаль, в Україні дослідження політичної думки часто не використовують повною мірою можливості політичної лінгвістики, лінгвополітології, аналізу дискурсу та інших напрямів і дисциплін, центральним предметом яких є мова та іiі складні феномени й прояви. Збагачення аналітичного інструментарію за допомогою підходів лінгвополітології та дискурс-аналізу можуть бути особливо корисними для глибшого вивчення історії політичної думки в Україні.

Аналіз актуальних досліджень. Дослідження мови політики та мови ідеології здійснюють багато різних науковців i, що цікаво, на основі різноманітних теоретико-методологічних засад. Приміром, у Росії розвивається дослідження російських політичних ідіом на засадах Кембриджської школи інтелектуальної історії [1], що застосовується до дослідження російської політичної мови в минулому (бо, вочевидь, дослідження сучасної російської неоімперської ідеології всередині самої Росії є вкрай ускладненими). Група китайських дослідників політики Гонконгу розробила «системно-функціональний аналіз політичного дискурсу» [17], за допомогою якого вони аналізують ідеологічний, жанровий, метафункціональний та інший виміри політичного дискурсу Гонконгу [17, с. 13], тобто використовують апарат лінгвістики. Фінський політолог-міжнародник П. Корхонен намагається дати відповідь на питання «що таке Азія?», використовуючи саме політичну лінгвістику для того, щоб довести, що «дослідження міжнародних відносин потребують політичної лінгвістики» [16, с. 131]. Німецький дослідник А. Музольфф аналізує, як за допомогою метафор тіла різні нації осмислюють себе [18]. Також популярним щодо дослідження політичного дискурсу залишається дискурс-аналіз, який активно розвивається і в Україні. Харківський гуманітарний центр переклав російською мовою низку класиків дослідження дискурсу, зокрема праці М. Йоргенсен і Л.Дж. Філліпс [5], Д. Матісона [8], М. Маєра, Р. Водак та інших. Для розвитку дискурс-аналізу в Україні безумовно знаковою є грунтовна монографія В. Кулика «Дискурс українських медій: ідентичності, ідеології, владні стосунки» [7], що вийшла друком ц 2010 р. Разом із тим дедалі відчутнішою стає потреба розроблення міждисциплінарного політико-лінгвістичного інструментарію для глибшого дослідження історії політичної думки в самій Україні. Таким чином, мета цієї сmammi полягає в розгляді можливостей застосування міждисциплінарних підходів лінгвополітології та дискурс-аналізу до дослідження історії політичної думки України. Оскільки і лінгвополітологія, i дискурс-аналіз $є$ широкими царинами, які неможливо навіть побіжно вписати в обсяг дослідницької статті, ми зосередимося на двох школах: уральській школі політичної лінгвістики та критичному дискурс-аналізі (КДА). Отже, досягнення поставленої мети потребує розв'язання таких завдань: 1) розкрити специфіку уральської школи політичної лінгвістики та пояснити їі основні дослідницькі напрями; 2) окреслити напрями досліджень у межах критичного дискурс-аналізу; 3) виділити перспективи застосування їхніх напрацювань саме до дослідження історії політичної думки України.

Виклад основного матеріалу. На пострадянському просторі досить відомою є так звана уральська школа політичної лінгвістики, що сформувалася довкола професора Анатолія Чудінова та його праць. Як пише російська дослідниця О. Кондратьєва, «уральська лінгвістична школа працює в рамках когнітивно-дискурсивної парадигми, до їі основних дослідницьких принципів належать антропоцентричність, експланаторність, експансіонізм, мультидисциплінарність, інтуїтивізм, визнання нерозривного зв'язку мовленнєвої діяльності та когніції, людини та ії мови, політики і культури» [6, с. 153]. Деякі 3 цих пунктів потребують окремого пояснення, як, приміром, «експансіонізм», про який дослідниця пише, що він як настанова цієї школи «проявляється у виході за межі властиво лінгвістики, в активному використанні для вирішення лінгвістичних проблем даних інших наук, приміром, психології, соціології, політології, антропології, етнології, нейронаук» [6, с. 153-154]. Такий принцип, як «інтуїтивність», який звучить, щонайменше, неоднозначно, а за умов більш скептичного ставлення - антинауково, О. Кондратьєва не розшифровує, але в наведених в iï публікації напрямах уральської школи політичної 
лінгвістики можна «між рядків» прочитати уподобання дослідників, тому припустімо, що йдеться про «чуття мови» та використання його як «інструменту» в пошуках нових лінгвополітичних феноменів.

Розгляньмо, якими є основні дослідницькі напрями уральської школи політичної лінгвістики, що їх наводить О. Кондратьєва. Починає вона, як і належить науковцю, з теоретико-методологічного напряму дослідження політичної комунікації, який вона сама називає «теоретичні основи напряму та методологія аналізу політичної комунікації» [6, с. 159], які, що, вочевидь, випливає з назви, стосуються розробки та вдосконалення понятійного апарату, уточнення термінології на позначення різних аспектів політичної лінгвістики та політичної комунікації. Сама уральська школа політичної лінгвістики почала формуватися в Росії з 1990-х рр., навчальний посібник А. Чудінова «Політична лінгвістика» вийшов у 2006 р. [9], станом на 2018 р. він перевидавався чотири рази [6, с. 155]. Також знаковим для розробки методології аналізу політичного дискурсу та вдосконалення його методик був і лишається журнал «Політична лінгвістика», який стабільно входить у Росії до десятки найцитованіших наукових журналів із мовознавства [6, с. 156]. Розробка теоретико-методологічних засад аналізу політичної комунікації з позицій лінгвістики популярна і в інших закордонних дослідженнях. Як приклад можна навести присвячену лінгвістиці політичної аргументації та політичних конфліктів працю А. Партінгтона, який працює в традиції корпусної лінгвістики [21].

Другим напрямом уральської школи є дослідження метафор, що його О. Кондратьєва називає «метафоричне моделювання в політичному дискурсі» [6, с. 159]. Представник уральської школи політично лінгвістики Е. Будаєв активно публікує наукові монографії, присвячені метафорології, що видно з назв його публікацій: «Порівняльна політична метафорологія», видана в 2011 р. [3], «Зарубіжна політична метафорологія», у співавторстві з А. Чудіновим, 2008 р. [4]. Дослідження метафор є дуже популярним напрямом як на пострадянському просторі, так і серед західних дослідників. Зокрема, вже згаданий на початку статті А. Музольфф присвятив кілька своїх праць дослідженню політичних метафор [19] у різних контекстах.

У межах уральської школи політичної лінгвістики метафори розглядаються як «когнітивні механізми, за допомогою яких абстрактні поняття осмислюються у термінах більш конкретних» [6, с. 159]. Вочевидь, метафори відіграють важливу роль у будь-якій комунікації, політичній зокрема. Скажімо, одна політична сила виступає проти відкриття ринку землі і висловлює свою позицію: «Земля - це мати, а мати продавати неможна». Емоційно відозва, безумовно, відгукнеться в реципієнта, на якого вона спрямована, але за умов, якщо він не осмислює іiі критично. У наведеному прикладі видається не зовсім обгрунтованим погляд на метафори як на когнітивний елемент осмислення на рівні конкретизації - у порівнянні землі з матір'ю ніякої конкретизації не відбувається. Ба більше, якщо насправді критично осмислити таке метафоричне повідомлення, то можна поцікавитися, чи можна мати «здавати в оренду», як це роблять власники землі, якщо вже землю порівнювати з матір'ю.

Уральська школа політичної лінгвістики також займається порівняльними дослідженнями політичної комунікації різних країн та «дослідженнями історичної динаміки політичної комунікації» [6, с. 160], і в межах цих напрямів науковці займаються «національними особливостями у способах сприйняття політичної дійсності» [6, с. 160]. Порівняльні дослідження політичних дискурсів різних лінгвокультур стають особливо актуальними в наш час, коли обмін інформацією відбувається практично миттєво, що, зокрема, відбивається на швидкому взаємозбагаченні узусів та вокабулярів. Термін «брекзіт» практично відразу поширився по всьому світу так само, як і «ленінопад» на позначення процесу декомунізації в Україні, що супроводжувався демонтажем пам’ятників В. Леніну і став відомим і за межами України.

Наступним напрямом досліджень уральської школи політичної лінгвістики О. Кондратьєва називає політичну лінгвоперсонологію, яка досліджує «специфіку проявів професійної мовної особистості в політичній сфері» [6, с. 160], а серед ідіостилів зарубіжних політиків, зокрема, називають ідіостиль Юлії Тимошенко [6, с. 160]. За останні роки особливу увагу дослідників привернув ідіостиль колишнього президента США Дональда Трампа, мову та мовлення якого досліджували, зокрема, французька перекладачка Б. Вієнно, книжка якої так і називається «Мова Трампа» [25], та американська дослідниця Дж. Склафані, що досліджувала мовлення Трампа з позицій соціолінгвістичної методології та намагалася проаналізувати цей феномен крізь призму політичних ідентичностей та медіадискурсів [23].

Цікавою видається лінгвополітична прогностика, в якій О. Кондратьва окреслює два напрями: когнітивно-дискурсивний, що займається дослідженням засобів, «спрямованих на репрезентацію майбутнього в політичному дискурсі» [6, с. 161], а також жанрово-дискурсивний напрям аналізу політичних прогнозів, у межах якого досліджується прогноз як жанр, виявляються маркери прогностичності тощо [6, с. 161]. Як відомо, складні суспільно-політичні процеси, в принципі, важко піддаються прогнозуванню через велику кількість факторів, взаємодія яких не піддається чіткому математико-статистичному 
моделюванню. Утім виглядає перспективною і цікавою саме ідея прогнозування розвитку ідеологій на основі його мовно-дискурсивних складників. Також варто зазначити дещо іронічну назву одного з підрозділів праці згаданого вже в цій статті науковця А. Музольффа: «Непередбачуваність розуміння політичних метафор» [20, с. 115].

Уральська школа політичної лінгвістики також займається дослідженням комунікативних стратегій і тактик у політичному дискурсі - цей напрям видається самоочевидним із назви і загалом суголосний світовим практикам досліджень політичної комунікації, натомість неочевидним виключно 3 назви (особливо для не-філологів) є такий напрям, як дослідження політичної прецедентності [6, с. 162], що стосується досліджень «прецедентних феноменів», а серед прикладів досліджень цього напряму О. Кондратьєва наводить вивчення антропонімів та топонімів, які були «ключовими для минулих епох і які стали прецедентними для сучасних мас-медій» [6, с. 162]. 3 цим напрямом видається пов'язаним і дослідження креолізованого політичного тексту [6, с. 161], а серед жанрів такого тексту виділяють три типи: політична карикатура, ілюстрація, плакат [6, с. 162]. Останній напрям роботи уральської школи політичної лінгвістики є дуже прикладним - лінгвістична експертиза конфліктних текстів та аналіз екстремістського дискурсу [6, с. 162]. Звісно, цей напрям так само добре представлений у публікаціях дослідників в інших країнах. Приміром, Дж.А. Епстейн у своїй збірці наукових есеїв, опублікованій ще у 1994 р., показав, як змінювалися радикальні вислови маргінальних діячів в Англії у період з 1790 по 1850 pp. [11]. У цьому ж контексті цікавим прикладом дослідження радикалізму та його втілення в мові $є$ «словник політичного насилля» Ф. Гербста [15]. Звісно, в російському контексті часто можна спостерігати зловживання з боку путінського політичного режиму, який вишукує екстремізм у висловлюваннях опозиційних політиків чи навіть у композиціях реперів, які скептично оцінюють перспективи Росії за умов нескінченого правління Путіна, критикують корупцію політичних еліт тощо. Також можна зазначити і те, що часто і $з$ позицій лівих та ультраліберальних активістів спостерігають завищені вимоги до політичної коректності, коли, приміром, мають місце перегляди творів минулого, які, на їхню думку, ображають чиїсь почуття. Австрійській філософ Н. Пфаллер назвав цей процес «зникненням мови дорослих», тому що всі стають «занадто чутливими» [22].

Окресливши основні дослідницькі напрями уральської школи політичної лінгвістики, поглянемо стисло на дослідження дискурсу. «Екстралінгвістичні фактори функціонування політичної комунікаціï» [2, с. 12] є в центрі уваги критичного дискурс-аналізу (далі - КДА), основними напрямами якого можна доповнити розглянуті напрями досліджень у межах уральської школи політичної лінгвістики задля формування методологічних засад дослідження політичних дискурсів в українському лінгвокультурному та політичному контекстах. Для розгляду підходів критичного дискурс-аналізу візьмемо типологію, розроблену вже згаданим представником уральської школи Е. Будаєвим [2]. Він пояснює, що визначення цього напряму дискурс-аналізу як критичного «використовується у подібних дослідженнях для того, щоб підкреслити зазвичай приховані для неспеціалістів зв'язки між мовою, владою та ідеологією» [2, с. 13]. Мабуть, найбільш показовою в цьому контексті є праця відомого представника КДА Н. Ферклафа «Мова та влада» [14]. Самі напрями КДА Е. Будаєв називає «теоретико-методологічними варіаціями» і виділяє серед них такі: 1) діалектично-реляційний підхід; 2) соціокогнітивний підхід; 3) дискурсивно-історичний підхід [ с. 13]. Окрім них, він також додатково згадує Дуйсбурзьку школу КДА та «опосередкований дискурс-аналіз» [2, с. 13-14]. Варто зазначити, що ці назви загалом суголосні і західній науковій традиції - приміром, вже згаданий Н. Ферклаф пише про «діалектично-реляційний підхід до аналізу дискурсу» [12]. У межах цього підходу автор оперує низкою понять, що стосуються відносин влади та їхнього (пере)розподілу, приміром «панування» (англ. dominance) та «спротив» (англ. resistance), а загальною спрямованістю аналізу є «семіотичне відображення конфлікту в політичному дискурсі» [2, с. 13]. Варто зазначити, що у своїй оглядовій статті Е. Будаєв справедливо зазначає, що КДА, як це дивно не звучить, критикують за його надмірну «критичність» і прагнення скрізь побачити якийсь владний конфлікт, у всьому вгледіти пригноблених і тих, хто їх пригноблює. Вочевидь, такий підхід відсилає нас до марксистської парадигми світобачення. Зі свого боку, представники КДА цього і не заперечують, а одну зі своїх спільних публікацій Н. Ферклаф та Ф.В. Грем так і назвали «Маркс як критичний аналітик дискурсу» [13].

Відомим представником соціокогнітивного підходу КДА є Т. ван Дейк [24], якого цікавлять зв'язки між когнітивними структурами, дискурсом і суспільством [12, с. 13]. Для дискурсивно-історичного підходу, яскравою представницею якого є Р. Водак [26], важливим є «поєднання текстуального і контекстуального рівнів аналізу» [12, с. 13], що супроводжується процесами деконтекстуалізації та реконтекстуалізації. Вочевидь, у контексті таких процедур у разі досліджень історії політичних учень вкрай важливо уникнути презентизму як намагання сформувати концепції минулого з позицій сучасності, що 
становить і методологічний виклик, і ризик для викривленого, ідеологічно навантаженого сприйняття минулого [10, с. 109].

Оскільки ми вже перейшли до розгляду можливих нюансів у застосуванні підходів дискурс-аналізу в дослідженні історії політичної думки, розгляньмо перспективи таких досліджень трохи детальніше. Одним із перших і загалом очевидних підходів є вже згаданий напрям політичної лінгвоперсонології: в будь-якого політичного вчення є принаймні кілька основних представників, які розробляли його у своїх працях. Відповідно, у творців текстів, особливо полемічного жанру, можна виділити жанрові та стилістичні особливості, аналіз яких може допомогти дати відповідь на питання, яке представники Кембриджської школи інтелектуальної історії вважали ключовим для розуміння історичних текстів: що хотів зробити автор своїм висловлюванням [1]? Окремо серед полемічних прийомів варто виділити метафори як особливо популярний предмет досліджень, що становить цілу галузь політичної метафорології. Приміром, для української політичної думки важливість здобуття незалежності від Росії та вихід iз СРСР метафорично яскраво ілюстрували як звільнення з «тюрми народів». Також окремим блоком може бути дослідження прогностичних прийомів і бачення майбутнього суспільства в межах певних історичних форм різних ідеологій - від «світлого майбутнього» до побудови справедливого суспільства на основах націоцентричності в рамках правих ідеологій. Окремим екстралінгвальним напрямом може бути дослідження карикатур, однак навіть тут науковці можуть взятися за більш широку сферу дослідження креолізованих політичних текстів із методологічних позицій постколоніальних студій, що особливо важливо для розуміння розвитку української політичної думки сучасності, в якій ностальгія за радянським минулим тісно переплітається 3 постколоніальним комплексом щодо імперського центру. У цьому розрізі для розуміння історії політичних ідей корисним може бути порівняльний розгляд стратегій політичної комунікації в різних лінгвокультурах у різні історичні періоди. Приміром, для сучасної нідерландської чи будь-якої скандинавської політичної культури поширення пліток про когось із політиків чи політикинь, нібито він чи вона належать до сексуальних меншин, ніяк не вплине на їхній імідж, однак для більш консервативних суспільств така стратегія (та, відповідно, увесь дискурс, що ії супроводжуватиме) матиме інший суспільний резонанс. Те саме може стосуватися і більш глобальних тем, довкола яких у суспільствах точаться дискусії, які своєю чергою формують відповідні дискурси. Дослідження дискурсів із критичних позицій означатиме приділення особливої уваги відносинам влади, а також тим, хто їі позбавляється. Такий погляд на розвиток політичних ідей як постійної боротьби за владу, хоч і видається марксистським, однак може бути дуже продуктивним за умов використання достатньої кількості емпіричного текстового матеріалу, що дає змогу ідентифікувати мовні стратегії легітимації одних владних порядків та формування позитивного образу іншого, бажаного чи пропагованого порядку. Саме застосування методологій і методик лінгвістичного аналізу до політичних текстів дасть змогу уникнути пустої балаканини з приводу якоїсь політичної критики і натомість уможливить їі грунтовний аналіз та порівняння з іншими ідеологічними позиціями.

Висновки та перспективи подальших досліджень. Огляд основних напрямів уральської школи політичної лінгвістики показує перспективність застосування міждисциплінарних лінгвополітологічних досліджень для грунтовного вивчення історії політичних ідей та вчень: політична лінгвоперсонологія, спрямована на дослідження ідіостилів ідеологів, уможливить глибше розуміння стратегій політичної аргументації, політологічна метафорологія поглиблює розуміння політичної комунікації, в тому числі в порівняльному розрізі, для розуміння дискурсів у різних історичних періодах і різних лінгвокультурних контекстах. Методологічні підвали критичного дискурс-аналізу, спрямованого на аналіз соціальної нерівності в суспільстві та орієнтованого на вияв його проявів в організації владних відносин, дадуть змогу глибше дослідити відношення між когнітивними структурами, дискурсом і суспільством. Саме в таких відношеннях і визрівають політичні ідеї, які потім часто важко де- чи реконтекстуалізувати без розуміння співвідношень між текстуальним та контекстуальними рівнями текстів, в яких вони представлені. Дослідження семіотичних відображень соціального конфлікту в політичному дискурсі видається перспективним напрямом для подальшого вдосконалення методології лінгвополітологічних досліджень історії політичних ідей, адже погляд на ідеології як на системи знаків і символів, скомпонованих особливим чином із метою посилення аргументативної сили висловлювань, уможливить неупереджений аналіз розвитку політичних ідей та захистить дослідників від пастки презентизму.

\section{Література:}

1. Атнашев Т., Велижев А. Кембриджская школа: история и метод. Кембриджская школа: теория и практика интеллектуальной истории / Сост. Т. Атнашев, М. Велижев. Москва : Новое литературное обозрение, 2018. С. 7-52.

2. Будаев Э.В. Критический анализ политического дискурса: основные направления современных зарубежных исследований. Политическая лингвистика. 2016. № 6(60). С. 12-17. 
3. Будаев Э.В. Сопоставительная политическая метафорология. Нижний Тагил : Нижнетагильская государственная социально-педагогическая академия, 2011. 330 с.

4. Будаев Э.В., Чудинов А.П. Зарубежная политическая метафорология. Екатеринбург : Урал. гос. пед. ун-т, 2008. $248 \mathrm{c}$.

5. Йоргенсен М. Филлипс Л.Дж. Дискурс-анализ. Теория и метод. Харьков : Из-во «Гуманитарный Центр», 2004. 334 с.

6. Кондратьева О.Н. Политика в зеркале языка и культуры: Уральская школа политической лингвистики. Язык и культура. 2018. № 9. С. 153-169.

7. Кулик В. Дискурс українських медій: ідентичності, ідеології, владні стосунки. Київ : «Критика», 2010. 655 с.

8. Матисон Д. Медиа-дискурс. Анализ медиа-текстов. Харьков : Из-во «Гуманитарный Центр», 2017.264 с.

9. Чудинов А.П. Политическая лингвистика. Москва : Флинта Наука, 2006. 254 с.

10. Яковлєв М.В. Минуле як відображення концепцій сучасності в міжнародних відносинах: обмеження та можливості презентизму. Актуальні проблеми політики. 2020. Вип. 66. С. 105-111.

11. Epstein J. Radical expression: Political Language, Ritual, and Symbol in England, 1790-1850. Oxford University Press. 1994.

12. Fairclough N. A Dialectical-Relational Approach to Critical Discourse Analysis. Methods of Critical Discourse Analysis. London: Sage, 2009. P. 162-168.

13. Fairclough N. Graham Ph. W. Marx as Critical Discourse Analyst: The Genesis of a Critical Method and its Relevance to the Critique of Global Capital. Critical Discourse Analysis: The Critical Study of Language. Routledge, 2010. P. 301-346.

14. Fairclough N. Language and Power. London, Routledge, 2015. 265 p.

15. Herbst P. Talking Terrorism: A Dictionary of the Loaded Language of Political Violence. Greenwood Press. 2003.

16. Korhonen P. What is Asia? International Studies as Political Linguistics / P. Aalto, V. Harle, S. Moisio (eds.). International Studies: Interdisciplinary Approaches. Basingstoke : Palgrave, 2012. P. 131-149.

17. Li E., Fung A., Lui P. Systemic functional political discourse analysis. Routledge, 2020. 256 p.

18. Musolff A. National conceptualisations of the body politic. Cultural Experience and Political Imagination. Springer Link. 2021. 207 p.

19. Musolff A. Metaphor and Political Discourse Analogical Reasoning in Debates about Europe. Palgrave Macmillan. 2004.

20. Musolff A. Political metaphor analysis. Discourse and Scenarios. Bloomsbury Academic. 2016. 194 p.

21. Partington A. The linguistics of political argument. The spin-doctor and the wolf-pack at the White House. Routledge. 2006.

22. Pfaller N. Erwachsenensprache: Über ihr Verschwinden aus Politik und Kultur. Frankfurt am Main, Fischer Verlag GmbH, 2017. $247 \mathrm{~s}$.

23. Sclafani J. Talking Donald Trump: A Sociolinguistic Study of Style, Metadiscourse, and Political Identity. Routledge. 2017.

24. Van Dijk T. Discourse and Knowledge. A Sociocognitive Approach. Cambridge: Cambridge University Press, 2014.407 p.

25. Viennot B. La langue du Tramp. Paris : Les Arènes, 2019. 153 p.

26. Wodak R. The Discourse-Historical Approach. Methods of Critical Discourse Analysis. London : Sage, 2009. P. 63-94. 